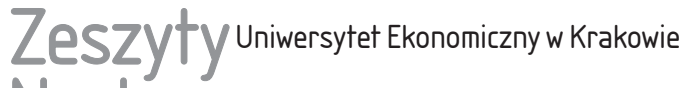 Naukowe
}

\section{Zarządzanie zyskiem w przemysłowych spółkach publicznych ukaranych przez Komisję Nadzoru Finansowego za nieprawidłowości w zakresie przestrzegania wytycznych MSR/MSSF}

\section{Streszczenie}

Cel: Celem artykułu jest analiza praktyk w zakresie rachunkowego zarządzania zyskiem w przemysłowych spółkach akcyjnych, w których KNF wykryła nieprawidłowości dotyczące niewypełniania lub nierzetelnego wypełniania obowiązku informacyjnego.

Metodyka badań: Do określenia skali i kierunków zarządzania zyskiem wykorzystano analizę całkowitych i bieżących dyskrecjonalnych różnic memoriałowych, szacowanych za pomocą modeli Jones oraz Dechow-Dicheva.

Michał Comporek, Uniwersytet Łódzki, Katedra Analizy i Strategii Przedsiębiorstwa, ul. Rewolucji 1905 r. nr 37, 90-214 Łódź, e-mail: michal.comporek@uni.lodz.pl, ORCID: https://orcid. org/0000-0002-1402-2505.

Artykuł udostępniany na licencji Creative Commons Uznanie autorstwa-Użycie niekomercyjne-Bez utworów zależnych 4.0 (CC BY-NC-ND 4.0); https://creativecommons.org/licenses/ by-nc-nd/4.0/ 
Wyniki badań: Wykazano, że w badanej populacji dominowały strategie intencjonalnego zmniejszania raportowanego wyniku finansowego netto. Udowodniono, że wartości dyskrecjonalnych różnic memoriałowych wyznaczane dla okresów, w odniesieniu do których wykryto nieprawidłowości, w sposób istotny statystycznie różniły się od wartości intencjonalnych korekt zysku netto estymowanych dla okresów wcześniejszych i późniejszych. Wnioski: Znaczne odchylenia wskaźników DACC i DCACC obserwowane z roku na rok mogą być postrzegane jako sygnał ostrzegawczy świadczący o możliwości wystąpienia niedozwolonych praktyk księgowych.

Wkład w rozwój dyscypliny: Zrealizowane badania wydają się istotne z punktu widzenia poszukiwania coraz precyzyjniejszych narzędzi umożliwiających ocenę cech jakościowych sprawozdań finansowych spółek działających na polskim rynku kapitałowym.

Słowa kluczowe: rachunkowe zarządzanie zyskiem, Komisja Nadzoru Finansowego, korekty zysku netto, przedsiębiorstwa przemysłowe.

Klasyfikacja JEL: G32, M40.

\section{Wprowadzenie}

Znajdujące wyraz w raportowanych danych finansowych rezultaty funkcjonowania podmiotu gospodarczego na rynku kapitałowym oraz analizowane sposoby i narzędzia ich realizacji stanowią główny przedmiot uwag oraz osądów i ocen formułowanych przez zróżnicowane grupy interesariuszy przedsiębiorstwa. Adresaci i użytkownicy sprawozdań finansowych nie tworzą jednolitej grupy, charakteryzują się bowiem różnymi wymaganiami określającymi problem, formę, sposoby, a nawet czas prezentacji danych zawartych w informacji sprawozdawczej. Szeroki zakres funkcji pełnionych przez raportowane dane finansowe wskazuje na mnogość potencjalnych przesłanek skłaniających do ich intencjonalnego kształtowania. Ramy tego typu działań są z jednej strony uwarunkowane postulowanym poziomem realizacji wyników finansowych, ustalanym na podstawie rynkowych, konkurencyjnych i umownych punktów referencyjnych, a z drugiej strony - celami, motywami, kompetencjami, możliwościami prawnymi i barierami psychologicznymi ingerowania w poziom raportowanych informacji sprawozdawczych.

Przyjęta w opracowaniu teza o istnieniu zróżnicowanych metod i technik intencjonalnego kształtowania wyniku finansowego upoważnia do wyeksponowania teleologicznego charakteru tego rodzaju zarządczej działalności kadry kierowniczej przedsiębiorstwa. Jest to bowiem przemyślany, nieprzypadkowy, konsekwentny i zaplanowany system zbierania, przetwarzania i ukazywania przetworzonej twórczo informacji o rezultatach działania przedsiębiorstwa, ukierunkowanej na zapewnienie dobrego wizerunku jednostki w oczach jego interesariuszy. Jak wskazuje literatura przedmiotu, jednym z ważniejszych instrumentów umożliwiających predykcję i ocenę tego typu działań jest analiza dyskrecjonalnych 
różnic memoriałowych w zakresie zarządzania wynikiem finansowym (Albu i in. 2014, s. 7-24; Hendryk i Hońko 2017b, s. 92).

Zasadniczym celem opracowania jest przedstawienie wyników badań empirycznych dotyczących implementowanych praktyk w zakresie rachunkowego zarządzania zyskiem (accrual-based earnings management) w przemysłowych spółkach publicznych notowanych na GPW w Warszawie, w których Komisja Nadzoru Finansowego wykryła nieprawidłowości polegające na niewypełnianiu lub nierzetelnym wypełnianiu obowiązku informacyjnego na podstawie przepisów: Ustawy z dnia 29 lipca 2005 r. o ofercie publicznej i warunkach wprowadzania instrumentów finansowych do zorganizowanego systemu obrotu oraz o spółkach publicznych, Ustawy z dnia 29 lipca 2005 r. o obrocie instrumentami finansowymi w okresie 2008-2016 i (lub) Rozporządzenia Parlamentu Europejskiego i Rady (UE) nr 596/2014 z dnia 16 kwietnia 2014 r. w sprawie nadużyć na rynku. Do tak określonej grupy przewinień zaliczyć można nieprawidłowości związane z: pomiarem utraty wartości aktywów (począwszy od braków odpowiednich ujawnień, braków testów na utratę wartości składników majątkowych czy błędnej amortyzacji wartości niematerialnych o nieokreślonym czasie użytkowania, a skończywszy na nieustalaniu wartości godziwej aktywów trwałych do zbycia i nieruchomości inwestycyjnych, błędnej wycenie wyrobów gotowych lub nienależytym wykazywaniu aktywów z tytułu odroczonego podatku), odstępstwami od norm rachunkowych w zakresie instrumentów finansowych (polegającymi na wykazaniu przeterminowanych należności, zawyżeniu wartości aktywów i pasywów przez wykazanie dostępnego limitu kredytowego w rachunku obrotowym, braku odpisów aktualizujących należności wobec dłużników mimo niskiego prawdopodobieństwa spłaty), nieodpowiednią wyceną wartości godziwej, brakiem odpowiednich ujawnien, opóźnianiem informacji poufnej itd. ${ }^{1}$ (zob. szerzej: Hendryk i Hońko 2017a, s. 49-65). Wdrożenie tychże działań miało, jak wskazuje sama KNF, „,istotny wpływ na wyniki finansowe emitenta” (Wykaz kar... 2019), a jednocześnie nosiło znamiona sztucznego ingerowania w wartość raportowanego zysku (straty) netto.

W opracowaniu wykorzystano dwuwymiarowe podejście do oceny rachunkowego zarządzania zyskiem w spółkach przemysłowych. Pierwszy wymiar koncentruje się na analizie całkowitych dyskrecjonalnych korekt zysku netto (discretionary accruals - DACC) wyodrębnianych za pomocą modelu Jones (1991). Drugi nawiązuje zaś do sfery uznaniowych bieżących różnic memoriałowych, utożsamianych z dyskrecjonalnymi zmianami niepieniężnych składników aktywów obrotowych netto (discretionary current accruals - DCACC) i wyodrębnianych przy użyciu modelu Dechow i Dicheva (2002).

\footnotetext{
${ }^{1}$ Niestety, w odniesieniu do konkretnych przedsiębiorstw KNF często posługuje się dość lapidarnymi i nieprecyzyjnymi określeniami popełnionych wykroczeń.
} 
Ponadto postawiono następujące pytania badawcze:

1) czy w spółkach ukaranych za nieprzestrzeganie wytycznych MSR/MSSF dominowały strategie intencjonalnego podwyższania, czy też obniżania wyniku finansowego?

2) czy poziom rachunkowego zarządzania zyskiem w spółkach ukaranych przez KNF różni się w sposób istotny statystycznie od skali tego typu działań w innych przedsiębiorstwach przemysłowych notowanych na GPW w Warszawie?

3) czy w podmiotach ukaranych przez KNF wartości intencjonalnych różnic memoriałowych w okresach poprzedzających lub następujących (okresy: $t-2$, $t-1, t+1, t+2)$ różnią się $\mathrm{w}$ sposób istotny statystycznie od wartości dyskrecjonalnych różnic memoriałowych obliczonych dla okresu, w stosunku do którego wykryto nieprawidłowości (okres $t$ )?

Badania empiryczne zostały zrealizowane na podstawie danych udostępnionych na stronie internetowej Polskiej Agencji Prasowej i przekazywanych do publicznej wiadomości za pośrednictwem Elektronicznego Systemu Przekazywania Informacji (ESPI) oraz informacji finansowych zaczerpniętych z bazy danych Notoria Serwis SA. Szerszy opis metodologii badawczej znajduje się w dalszej części artykułu.

\section{Istota rachunkowego kształtowania wyniku finansowego przedsiębiorstwa}

Koncepcja kształtowania wyniku finansowego typu rachunkowego wiąże zarządzanie zyskiem z wykorzystywaniem elastyczności i uznaniowości w sprawozdawczości finansowej, przy czym moralne uzasadnienie podejmowanych działań może być różne. Zaprezentowane w tabeli 1 poglądy różnych autorów dotyczące terminologicznego ujęcia praktyk księgowego zarządzania zyskiem wskazują na odmienność motywów ich implementacji. Ogólnie rzecz biorąc, uwypuklona została teza, że intencjonalne kształtowanie wyniku finansowego służy takiemu wyeksponowaniu raportowanych informacji, które ukaże sytuację finansową podmiotu w korzystniejszym świetle jego interesariuszom i (lub) utrudni im dostrzeżenie zjawisk i procesów odzwierciedlających potencjalne słabości przedsiębiorstwa. W większości przypadków jest ono pojmowane jako zjawisko szkodliwe, obniżające jakość i wiarygodność raportowanych danych sprawozdawczych.

Przyczyny i motywy rachunkowego zarządzania zyskiem mogą być różne i wahają się od chęci zaspokojenia oczekiwań analityków po zachęty związane $\mathrm{z}$ realizacją premii lub utrzymaniem pozycji konkurencyjnej na rynku finansowym. Źródeł potencjalnych ingerencji w wartość wykazywanego wyniku finansowego upatrywać należy choćby w założeniach tkwiących w teorii agencji (agency theory, 
Tabela 1. Wybrane definicje zarządzania zyskiem typu rachunkowego

\begin{tabular}{|c|c|}
\hline Autor & Definicja \\
\hline K. Schipper & $\begin{array}{l}\text { Zarządzanie zyskiem to celowe i świadome ingerowanie w proces sporzą- } \\
\text { dzania sprawozdań finansowych w celu osiągnięcia konkretnych korzyści } \\
\text { osobistych przez menedżerów jednostki / Earnings management is a purpose- } \\
\text { ful intervention in the external financial reporting process, with the intent of } \\
\text { obtaining some private gain }(1989, \text { s. } 91-102) \text {. }\end{array}$ \\
\hline $\begin{array}{l}\text { M. Fischer } \\
\text { i K. Rozenzweig }\end{array}$ & $\begin{array}{l}\text { Zarządzanie zyskiem obejmuje działania, których celem jest zwiększenie lub } \\
\text { zmniejszenie wyniku finansowego podmiotu sprawozdawczego, za które odpo- } \\
\text { wiedzialne jest kierownictwo, przy czym kształtowanie to nie koresponduje ze } \\
\text { wzrostem albo spadkiem długoterminowej rentowności podmiotu / We define } \\
\text { earnings management as referring to actions of a manager which serve to } \\
\text { increase (decrease) current reported earnings of the unit for which the mana- } \\
\text { ger is responsible without generating a corresponding increase (decrease) } \\
\text { in the long-term economic profitability of the unit (1995, s. 434). }\end{array}$ \\
\hline $\begin{array}{l}\text { P.M. Healy } \\
\text { i J.M. Wahlen }\end{array}$ & $\begin{array}{l}\text { Zarządzanie zyskiem wiąże się z manipulowaniem wartością wykazywanego } \\
\text { zysku netto w celu odpowiedniego dostosowania sprawozdania finansowego } \\
\text { do potrzeb określonej grupy interesariuszy przedsiębiorstwa przy jedno- } \\
\text { czesnym wprowadzeniu w błąd niektórych akcjonariuszy oraz uczestników } \\
\text { zawieranych transakcji co do założeń ekonomicznych firmy oraz wpłynięciu } \\
\text { na realizację kontraktów, od których zależą jej wyniki finansowe / Earnings } \\
\text { management occurs when managers use judgment in financial reporting and } \\
\text { in structuring transactions to alter financial reports to either mislead some } \\
\text { stakeholders about the underlying economic performance of the company } \\
\text { or to influence contractual outcomes that depend on reported accounting } \\
\text { practices }(1999, \text { s. 365-383). }\end{array}$ \\
\hline P. Wójtowicz & $\begin{array}{l}\text { Możliwość kształtowania wyniku finansowego jest wynikiem tego, że zarzą- } \\
\text { dzający stosują profesjonalny osąd, który może być wykorzystywany przeciwko } \\
\text { innym użytkownikom sprawozdań finansowych }(2010, \text { s. } 85) \text {. }\end{array}$ \\
\hline M. Smejda & $\begin{array}{l}\text { Zjawisko zarządzania zyskami należy kojarzyć z zabiegami celowo fałszują- } \\
\text { cymi dane rachunkowości, aby spowodować określony skutek w zewnętrznej } \\
\text { alokacji zasobów. Pierwotnie założona jest tu celowość - interes ekonomiczny } \\
\text { polegający na przypływie gotówki (2012, s. 175-176). }\end{array}$ \\
\hline
\end{tabular}

Źródło: opracowanie własne na podstawie (Schipper 1989, Fischer i Rozenzweig 1995, Healy i Wahlen 1999, Wójtowicz 2010, Smejda 2012).

zob. m.in.: Jensen i Meckling 1976, s. 305-360; Paiva, Lourenco i Branco 2016, s. 85-100), teorii interesariuszy (stakeholders theory, zob. m.in.: Mitchell, Agle i Wood 1997, s. 872; Nita 2016, s. 120) czy hipotezach planu premiowego (zob. m.in.: Rahman, Moniruzzaman i Sharif 2013, s. 31 i nast.). Przyjmując, że w znacznej mierze motywy implementacji earnings management zawierają się $\mathrm{w}$ szerokim spektrum funkcji informacyjnych, motywacyjnych i sprawozdawczych pełnionych przez wynik bilansowy, zauważyć należy, iż kadra kierownicza dążyć może zarówno do sztucznego zawyżania, jak i zaniżania raportowanych rezultatów dzia- 
łalności przedsiębiorstwa. Przesłankami skłaniającymi do stwarzania zbyt pozytywnego obrazu jednostki gospodarczej mogą być m.in.: dążenie do utrzymania i podwyższania gotowości kredytowej podmiotu, zachęcanie nowych akcjonariuszy do nabycia akcji nowych emisji lub powstrzymywania się od wyprzedaży dotąd posiadanych akcji, przekonanie pracowników o pewności posiadanej pracy, wzrost zaufania wśród klientów co do ciągłości realizowanych umów. Z kolei tworzenie zbyt negatywnego wizerunku przedsiębiorstwa może skutkować: potencjalną zgodą wierzycieli na wydłużanie terminów spłaty pożyczek i kredytów, brakiem żądań akcjonariuszy odnośnie do wypłacania dywidendy, przekonaniem Skarbu Państwa, że podmiot nie osiąga zysków, od których należałoby odprowadzać podatek.

Na rys. 1 zaprezentowano ogólny model procesu zarządzania wynikiem finansowym w podmiocie gospodarczym, którego autorem jest L. Babalyan (2004, s. 38). Model ten stanowi, że menedżerowie odczuwają zachęty do maksymalizacji własnej funkcji użyteczności, lecz ramy instytucjonalne, wewnętrzne struktury zarządzania, a także standardy etyczne stanowią ograniczenia w tym zakresie.

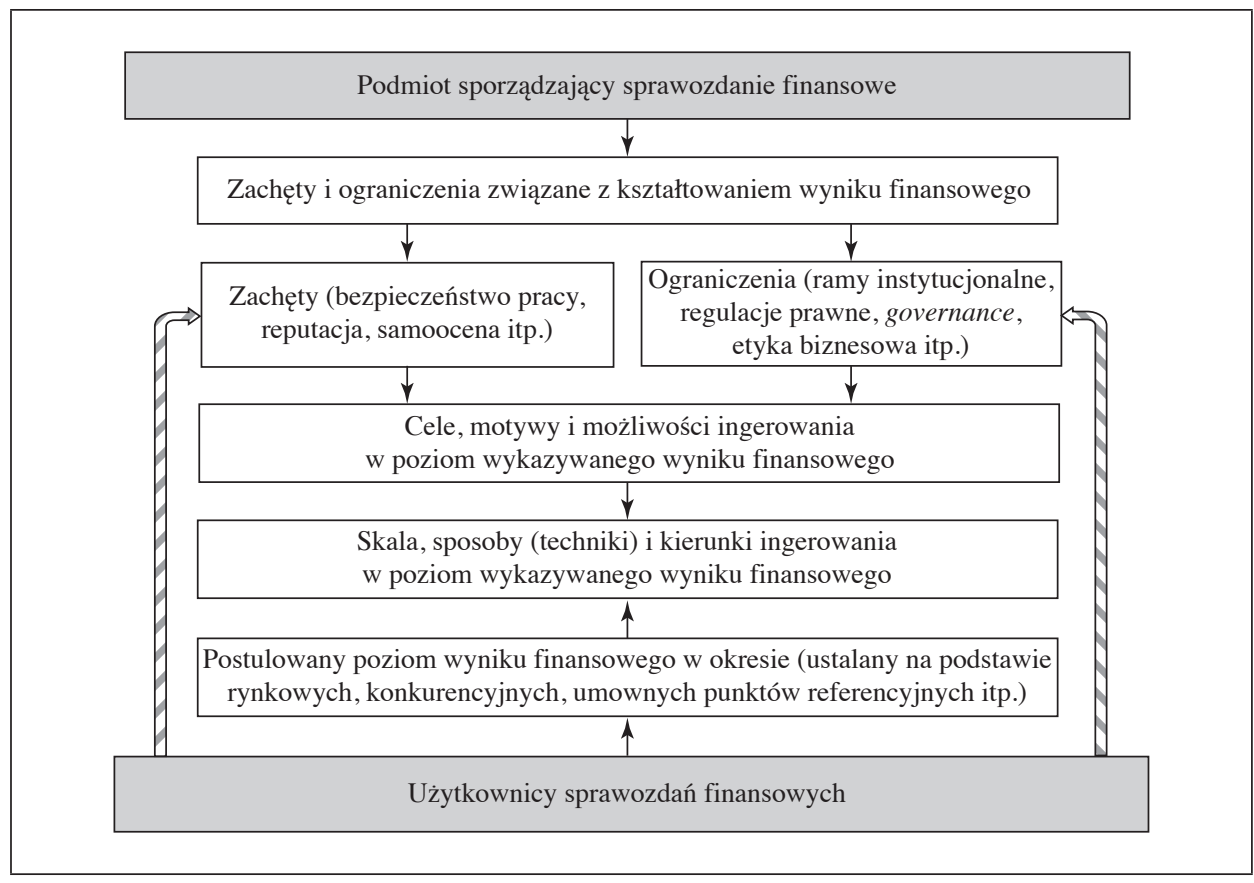

Rys. 1. Zgeneralizowany model intencjonalnego kształtowania wyniku finansowego Źródło: opracowanie własne na podstawie (Babalyan 2004).

Jednocześnie na skalę i przyjęte sposoby zarządzania zyskami wpływają nie tylko bodźce i ograniczenia natury zarządczej, ale także zapotrzebowanie użyt- 
kowników sprawozdań finansowych. Oznacza to, że istnieje pętla sprzężenia zwrotnego między stymulantami i przeszkodami w zakresie działań ukierunkowanych na celową ingerencję w wartość raportowanego wyniku oraz oczekiwaniami i żądaniami zgłaszanymi przez odbiorców informacji sprawozdawczej.

\section{Metodologia badań i charakterystyka próby badawczej}

W badanej zbiorowości znalazły się przedsiębiorstwa wytwórcze, których akcje były przedmiotem obrotu na rynku głównym GPW w Warszawie przez minimum osiem lat w przyjętym horyzoncie odniesienia 2006-2017. Dodatkowymi kryteriami kwalifikowania przedsiębiorstw do analizy empirycznej były: dostępność rocznych jednostkowych sprawozdań finansowych, kompletność raportowanych danych finansowych, utrzymywanie okresu obrachunkowego kończącego się 31 grudnia danego roku, brak postawienia spółki w stan likwidacji lub upadłości. W efekcie w badaniach uwzględniono 68 przedsiębiorstw, z czego 17 stanowiły podmioty ukarane przez KNF (co przełożyło się na $n=202$ obserwacje), zaś 57 spółki niekarane $(n=593 \text { obserwacje })^{2}$.

Za zasadniczą zmienną wykorzystywaną do oceny zjawiska zarządzania zyskiem uznane zostały intencjonalne różnice memoriałowe (korekty zysku netto). Kategoria ta jest uznawana w literaturze przedmiotu za ważny instrument predykcji zakresu i skali rachunkowego kształtowania wyniku finansowego przedsiębiorstw ${ }^{3}$.

Jak zasygnalizowano we wprowadzeniu, ocena całkowitych dyskrecjonalnych różnic memoriałowych $D A C C$ przeprowadzona została z wykorzystaniem modelu Jones (1991). Przyjmuje się w nim, że wartość operacyjnych (normalnych) różnic memoriałowych jest determinowana przez dwie zmienne: przyrost absolutny łańcuchowy przychodów ze sprzedaży oraz średnią wartość rzeczowych aktywów

2 Teoretycznie w tej grupie mogą również znajdować się podmioty nieobjęte badaniami. Jak bowiem zauważają M. Hendryk i S. Hońko: „KNF dobiera próbę badawczą, stosując model mieszany, oparty na analizie ryzyka z podejściem rotacyjnym lub podejściem pobierania próbek. Nadaje przy tym wysoki priorytet sprawozdaniom z zastrzeżeniami biegłego rewidenta, odmową wyrażenia opinii bądź opinią negatywną, a także sprawozdaniom tych emitentów, których kontynuacja działalności jest zagrożona” (Hendryk i Hońko 2017a, s. 59).

${ }^{3}$ Interpretacja szacowanych wartości korekt dyskrecjonalnych może być przy tym odmienna u różnych autorów. Przykładowo I. Amara przyjmuje, że spółki wykazujące ujemne wartości dyskrecjonalnych różnic memoriałowych można uznać za podmioty wdrażające konserwatywne strategie rachunkowości, podczas gdy podmioty z dodatnimi wartościami tychże różnic stosują strategie agresywne (2017, s. 52). S.S. Yang przyjmuje, że istotna jest zarówno ocena wartości, jak i znaku stojącego przed estymowaną wartością korekt intencjonalnych, gdyż te wskazują na skalę i kierunki zarządzania zyskiem (2005, s. 3-4). Z kolei J. Kerstein i A. Rai dopuszczają wykorzystywanie w analizach bezwzględnych wartości dyskrecjonalnych różnic memoriałowych w celu predykcji zakresu earnings management (2007, s. 33-43). 
trwałych. Z kolei wartość intencjonalnych korekt zysku netto (DACC) została wyznaczona na podstawie różnicy między wartością empiryczną a teoretyczną zmiennej obrazującej całkowity poziom korekt zysku netto ${ }^{4}$ (a zatem zgodnie z założeniami modelu regresji jest równa wartości błędu losowego). Model ten pozbawiony jest wyrazu wolnego, co jest wynikiem skalowania zmiennych endoi egzogenicznych za pomocą wskaźnika obrazującego poziom aktywów całkowitych okresu poprzedzającego analizę. Można zatem zauważyć, że skoro:

$$
\frac{T A C C_{t}}{T A_{t-1}}=\alpha_{1}\left(\frac{1}{T A_{t-1}}\right)+\alpha_{2}\left(\frac{\Delta R E V_{t}}{T A_{t-1}}\right)+\alpha_{3}\left(\frac{P P E_{t}}{T A_{t-1}}\right)+\varepsilon_{t}^{\text {Jones }},
$$

to:

$$
\varepsilon_{t}^{\text {Jones }}=\frac{T A C C_{t}}{T A_{t-1}}-\left[\alpha_{1}\left(\frac{1}{T A_{t-1}}\right)+\alpha_{2}\left(\frac{\Delta R E V_{t}}{T A_{t-1}}\right)+\alpha_{3}\left(\frac{P P E_{t}}{T A_{t-1}}\right)\right]
$$

oraz

$$
\varepsilon_{t}^{\text {Jones }}=D A C C_{t \text { Jones }} \text {, }
$$

gdzie:

$D A C C_{t \text { Jones }}$ - współczynnik dyskrecjonalnych korekt zysku netto (dyskrecjonalnych różnic memoriałowych) wyodrębnianych za pomocą modelu Jones w roku $t$,

$T A C C_{t}-$ całkowite korekty zysku netto $\mathrm{w}$ roku $t$,

$T A_{t}$ - wartość aktywów ogółem w roku $t$,

$P P E_{t}$ - wartość rzeczowych aktywów trwałych w roku $t$,

$R E V_{t}-$ przychody ze sprzedaży w roku $t$,

$\alpha_{1}, i=0,1, \ldots, k$ - parametry modelu regresji,

$\varepsilon_{t}-$ błąd losowy.

Natomiast drugi wykorzystany model ekonometryczny, autorstwa P.M. Dechow oraz I.D. Dicheva (2002), posłużył do oceny intencjonalnych bieżących różnic memoriałowych, traktowanych w literaturze przedmiotu również jako dyskrecjonalne zmiany niepieniężnych składników aktywów obrotowych netto (discretionary current accruals - DCACC) (zob. Kształtowanie zysków... 2013). W modelu tym zmienną objaśnianą tworzy wartość bieżących (current accruals) różnic memoriałowych, stanowiąca sumę nieuznaniowych (non-discretionary current accruals - NDACC) i uznaniowych bieżących różnic memoriałowych (DCACC). Można to bowiem przedstawić za pomocą następującej formuły:

$$
C A C C_{t}=N D C A C C_{t}+D C A C C_{t} \text {, }
$$

${ }^{4} \mathrm{~W}$ analizie przyjęto przy tym, że wartość całkowitych różnic memoriałowych TACC jest szacowana jako różnica między zyskiem netto a operacyjnymi przepływami pieniężnymi. 
gdzie:

$C A C C_{t}-$ wartość bieżących różnic memoriałowych w roku $t$,

$N D C A C C_{t}-$ wartość operacyjnych bieżących różnic memoriałowych w roku $t$, $D C A C C_{t}$ - wartość dyskrecjonalnych bieżących różnic memoriałowych w roku $t$.

Jednocześnie do opisania zmiennej endogenicznej CACC posłużyć mogą wzory:

$$
C A C C_{t}=\Delta R E C_{t}+\Delta I N V_{t}-\Delta T P A Y_{t}-\Delta C T L_{t}
$$

oraz

$$
\frac{C A C C_{t}}{T A_{t-1}}=\alpha_{1}\left(\frac{1}{T A_{t-1}}\right)+\alpha_{2}\left(\frac{O C F_{t-1}}{T A_{t-1}}\right)+\alpha_{3}\left(\frac{O C F_{t}}{T A_{t-1}}\right)+\alpha_{4}\left(\frac{O C F_{t+1}}{T A_{t-1}}\right)+\varepsilon_{t}^{\text {Dechow-Dichev }},
$$

gdzie:

$T P A Y_{t}-$ zobowiązania z tytułu dostaw w roku $t$,

$C T L_{t}-$ zobowiązania z tytułu podatków w roku $t$,

$R E C_{t}-$ należności krótkoterminowe w roku $t$,

$I N V_{t}$ - zapasy w roku $t$,

$O C F_{t}$ - operacyjne przepływy pieniężne w roku $t$,

pozostałe oznaczenia - jak uprzednio.

Ponieważ wartości resztowe powyższego równania odzwierciedlają zmiany niepieniężnych aktywów obrotowych netto, które nie są powiązane z operacyjnymi przepływami pieniężnymi, wykazać można, że:

$$
\varepsilon_{t}^{\text {Dechow-Dichev }}=\frac{C A C C_{t}}{T A_{t-1}}-\left[\alpha_{1}\left(\frac{1}{T A_{t-1}}\right)+\alpha_{2}\left(\frac{O C F_{t-1}}{T A_{t-1}}\right)+\alpha_{3}\left(\frac{O C F_{t}}{T A_{t-1}}\right)+\alpha_{4}\left(\frac{O C F_{t+1}}{T A_{t-1}}\right)\right],
$$

a zarazem:

$$
\varepsilon_{t}^{\text {Dechow-Dichev }}=D C A C C_{t \text { Dechow-Dichev }},
$$

gdzie:

$D C A C C_{t \text { Dechow-Dichev }}$ - współczynnik dyskrecjonalnych bieżących różnic memoriałowych, wyodrębnianych za pomocą modelu Dechow-Dicheva w roku $t$,

pozostałe oznaczenia - jak uprzednio.

\section{Wyniki badań empirycznych}

\subsection{Ocena rachunkowego zarządzania zyskiem na podstawie całkowitych intencjonalnych różnic memoriałowych}

Przeprowadzone badania empiryczne wykazały, że w grupie przemysłowych spółek giełdowych model Jones cechuje się przeciętnym stopniem dopasowania do 
danych empirycznych (zob. tabela 2). Przy ocenie zmienności całkowitych korekt zysku netto (TACC) z wykorzystaniem przychodów ze sprzedaży oraz rzeczowych aktywów trwałych jako predyktorów zmiennej zależnej uzyskano ok. 50\% przedsiębiorstw charakteryzujących się zadowalającym (wartość skorygowanego współczynnika determinacji $R^{2}>0,3$ ) oraz dobrym (wartość skorygowanego współczynnika determinacji $\left.R^{2}>0,5\right)$ zakresem dopasowania zmiennych objaśniających do zmiennej objaśnianej. Jednocześnie, opierając się na danych zawartych w tabeli 2 , podkreślić należy, że dla blisko $34 \%$ badanej populacji istnieją podstawy do odrzucenia hipotezy zerowej (przy poziomie istotności $\alpha=0,05$ ), mówiącej, że współczynnik $R^{2}$ jest nieistotny statystycznie. Przy poziomie istotności $\alpha=0,01$ odsetek ten radykalnie maleje i wynosi ok. $3 \%$.

Tabela 2. Stopień dopasowania modelu Jones służącego do wyznaczania całkowitych różnic memoriałowych $(T A C C)$ w przemysłowych spółkach publicznych

\begin{tabular}{|c|c|c|c|c|c|c|c|}
\hline \multicolumn{6}{|c|}{$\begin{array}{l}\text { Udział przedsiębiorstw, dla których współczynniki dopasowania } \\
\text { modelu osiągały wartości }\end{array}$} & \multicolumn{2}{|c|}{$\begin{array}{c}\text { Udział przedsię- } \\
\text { biorstw, dla których } \\
\text { obliczone współ- } \\
\text { czynniki dopasowania } \\
\text { modelu były istotne } \\
\text { statystycznie } \\
\text { dla danego poziomu } \\
\text { istotności }\end{array}$} \\
\hline$R^{2}>0,1$ & $R^{2}>0,3$ & $R^{2}>0,5$ & $\begin{array}{l}\text { skoryg. } \\
R^{2}>0,1\end{array}$ & $\begin{array}{l}\text { skoryg. } \\
R^{2}>0,3\end{array}$ & $\begin{array}{l}\text { skoryg. } \\
R^{2}>0,5\end{array}$ & $\begin{array}{l}p \text {-value }= \\
\quad=0,05\end{array}$ & $\begin{array}{l}p \text {-value }= \\
\quad=0,01\end{array}$ \\
\hline $92,96 \%$ & $63,38 \%$ & $30,99 \%$ & $63,38 \%$ & $38,03 \%$ & $12,68 \%$ & $33,80 \%$ & $2,82 \%$ \\
\hline
\end{tabular}

Źródło: opracowanie własne.

Z przeprowadzonych badań empirycznych wynika, że zarówno w spółkach ukaranych przez KNF za nieprzestrzeganie wytycznych MSR/MSSF, jak i w pozostałych podmiotach poddanych analizie dominowały strategie intencjonalnego obniżania wyniku finansowego (zob. rys. 2). Na tego typu praktyki wskazują średnie 12-letnie wartości całkowitych dyskrecjonalnych różnic memoriałowych (DACC) obliczone dla poszczególnych podpopulacji.

Przeprowadzony test Manna-Whitneya-Wilcoxona, którego wyniki zaprezentowano w tabeli 3 , wskazuje na brak podstaw do odrzucenia hipotezy zerowej $H_{0}$, mówiącej o równości średniego poziomu współczynnika $D A C C$ w obrębie obu rozważanych podpopulacji. Oznacza to, że w tak dobranej próbie badawczej nie znajduje potwierdzenia założenie, że poziom rachunkowego zarządzania zyskiem w spółkach ukaranych przez KNF różni się w sposób istotny statystycznie od skali tego typu działań w innych przedsiębiorstwach przemysłowych notowanych na GPW w Warszawie. 


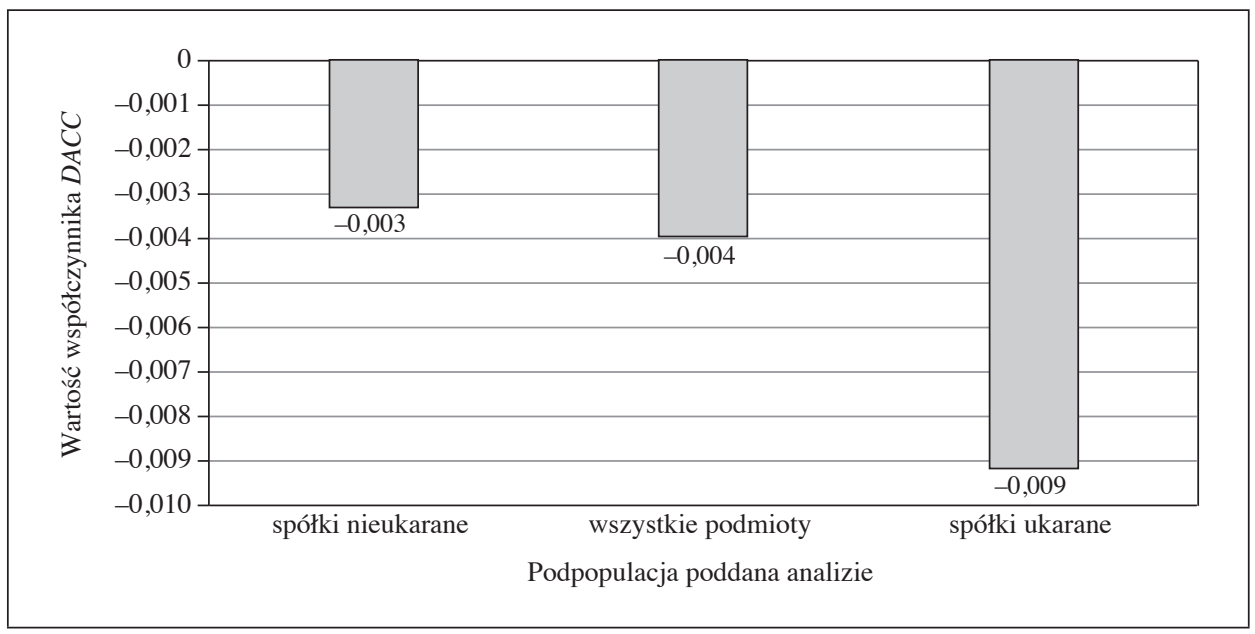

Rys. 2. Średnie 12-letnie wartości współczynnika dyskrecjonalnych całkowitych różnic memoriałowych (wyodrębnianych za pomocą modelu Jones) w poszczególnych podpopulacjach

Źródło: opracowanie własne.

Tabela 3. Wyniki testu Manna-Whitneya-Wilcoxona dotyczącego statystycznego różnicowania zmiennej $D A C C$ w obrębie spółek ukaranych i nieukaranych przez KNF

\begin{tabular}{|l|c|c|c|c|c|c|}
\hline \multicolumn{1}{|c|}{ Spółki } & $\begin{array}{c}\text { Średnia } \\
\text { ranga }\end{array}$ & Suma rang & $\begin{array}{c}U \text { Manna- } \\
\text {-Whitneya }\end{array}$ & $\begin{array}{c}W \\
\text { Wilcoxona }\end{array}$ & $Z$ & $\begin{array}{c}\text { Istotność } \\
\text { asymptotyczna }\end{array}$ \\
\hline $\begin{array}{l}\text { Niekarane } \\
(n=593)\end{array}$ & 394,02 & 233654,50 & 57533,50 & 233654,50 & $-0,837$ & 0,403 \\
\cline { 1 - 3 }$\left(\begin{array}{l}\text { Karane } \\
(n=202)\end{array}\right.$ & 409,68 & 82755,50 & & & & \\
\hline
\end{tabular}

Źródło: opracowanie własne.

Interesujące wnioski płyną z analizy przeprowadzonych badań empirycznych dotyczących kształtowania średnich i środkowych wartości współczynnika całkowitych intencjonalnych różnic memoriałowych $D A C C$ w okresach, względem których KNF wykryła nieprawidłowości (okres $t$ ), jak również w latach poprzedzających $(t-2, t-1)$ lub bezpośrednio po nich następujących $(t+1, t+2)$ (zob. rys. 3). Rezultaty analiz wskazują, że w okresach, za które KNF nakładała sankcje na spółki publiczne, notowano ponadprzeciętne, ujemne wartości całkowitych dyskrecjonalnych korekt zysku netto. Z kolei w okresach wcześniejszych i późniejszych, dla których nie wykryto nieprawidłowości w odniesieniu do wytycznych MSR/MSSF, obliczone średnie i środkowe wartości współczynnika $D A C C$ były dodatnie. 


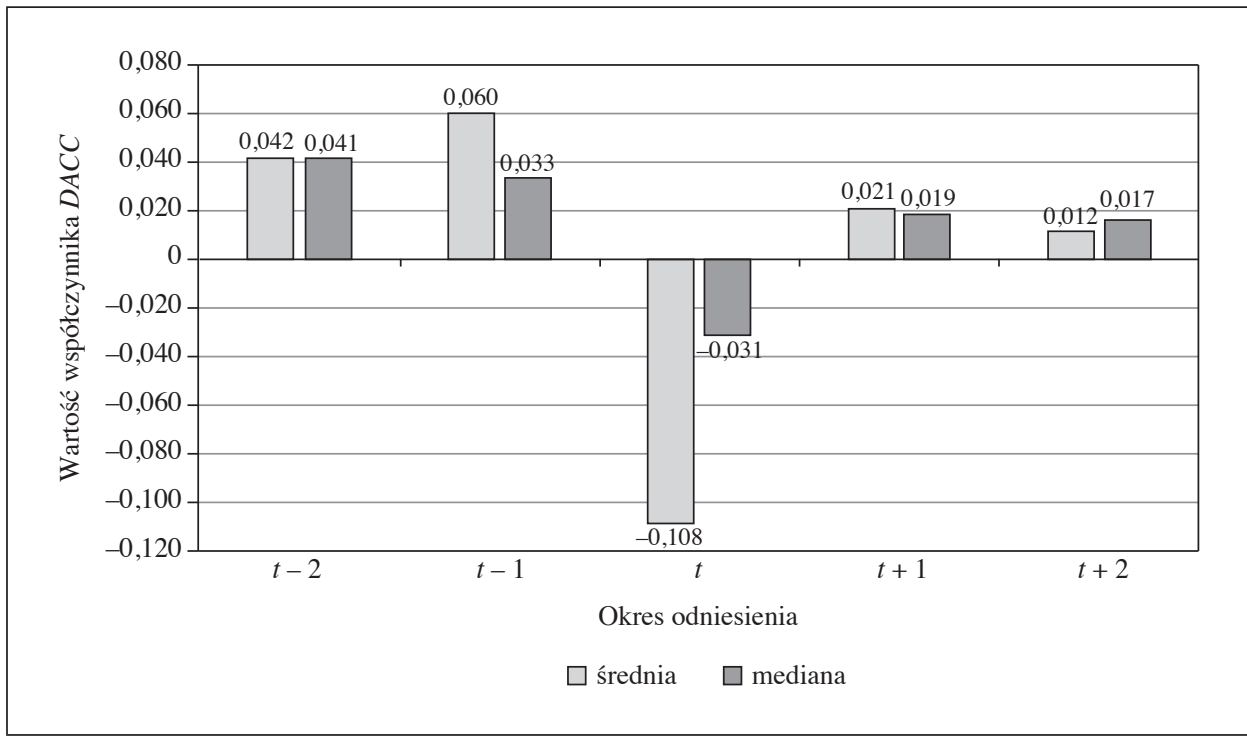

Rys. 3. Średnie i środkowe wartości współczynnika dyskrecjonalnych całkowitych różnic memoriałowych $D A C C$ obliczone dla spółek przemysłowych ukaranych przez KNF (według okresów odniesienia).

Źródło: opracowanie własne.

Dla pełniejszego rozpoznania zależności pomiędzy wartością korekt dyskrecjonalnych a sankcjami nakładanymi przez KNF w związku z naruszaniem wymogów MSR/MSSF wartości miar obrazujących poziom zarządzania zyskiem w okresach poprzedzających (okresy $t-2$ i $t-1$ ) i następujących po roku (okresy $t+1$ oraz $t+2$ ), dla którego wykazano nieprawidłowości, porównano z wynikami współczynników DACC obliczonymi dla okresów, w stosunku do których KNF udowodniła naruszanie ram rachunkowości (okres $t$ ) - zob. tabela 4 .

W tym celu skorzystano z testu znakowanych rang Wilcoxona. Przyjęta hipoteza zerowa $\left(H_{0}\right)$ zakładała, że w badanej populacji nie ma różnic między pomiarami, zaś hipoteza alternatywna $\left(H_{1}\right)$ orzekała, że wartości dyskrecjonalnych różnic memoriałowych będą się statystycznie różnić w przyjętych horyzontach odniesienia. $\mathrm{Z}$ analizy badań empirycznych wynika, że hipoteza alternatywna znalazła potwierdzenie $\mathrm{w}$ odniesieniu do porównań dotyczących okresów poprzedzających $(t-2, t-1)$ oraz lat, dla których wykryto naruszenia wytycznych MSR/MSSF. $\mathrm{Z}$ kolei w odniesieniu do okresów kolejnych $(t+1, t+2) \mathrm{w}$ żadnym $\mathrm{z}$ analizowanych przypadków nie znaleziono podstaw do odrzucenia hipotezy $H_{0}$ na rzecz hipotezy alternatywnej $H_{1}$ (zob. tabela 4). 
Tabela 4. Analiza zmian wartości mediany współczynników dyskrecjonalnych korekt zysku netto $D A C C$ w spółkach przemysłowych ukaranych przez KNF za nieprzestrzeganie reguł MSR/MSSF w horyzoncie 2006-2017

\begin{tabular}{|c|c|c|c|c|}
\hline $\begin{array}{c}\text { Porównywane } \\
\text { okresy }\end{array}$ & Wyszczególnienie & $N$ & Średnia ranga & Suma rang \\
\hline \multirow[t]{6}{*}{$t / t-2$} & Ujemne rangi & 4 & 6,25 & 25,00 \\
\hline & Dodatnie rangi & 13 & 9,85 & 128,00 \\
\hline & Wiązania & 0 & - & - \\
\hline & Ogółem & 17 & - & - \\
\hline & Z & $-2,439$ & - & - \\
\hline & Istotność asymptotyczna & 0,015 & - & - \\
\hline \multirow[t]{6}{*}{$t / t-1$} & Ujemne rangi & 6 & 4,50 & 27,00 \\
\hline & Dodatnie rangi & 11 & 11,45 & 126,00 \\
\hline & Wiązania & 0 & - & - \\
\hline & Ogółem & 17 & - & - \\
\hline & $Z$ & $-2,344$ & - & - \\
\hline & Istotność asymptotyczna & 0,019 & - & - \\
\hline \multirow[t]{6}{*}{$t / t+1$} & Ujemne rangi & 5 & 8,20 & 41,00 \\
\hline & Dodatnie rangi & 12 & 9,33 & 112,00 \\
\hline & Wiązania & 0 & - & - \\
\hline & Ogółem & 17 & - & - \\
\hline & $Z$ & $-1,681$ & - & - \\
\hline & Istotność asymptotyczna & 0,093 & - & - \\
\hline \multirow[t]{6}{*}{$t / t+2$} & Ujemne rangi & 5 & 8,40 & 42,00 \\
\hline & Dodatnie rangi & 12 & 9,25 & 111,00 \\
\hline & Wiązania & 0 & - & - \\
\hline & Ogółem & 17 & - & - \\
\hline & $Z$ & $-1,633$ & - & - \\
\hline & Istotność asymptotyczna & 0,102 & - & - \\
\hline
\end{tabular}

Źródło: opracowanie własne.

\subsection{Ocena księgowego zarządzania zyskiem na podstawie dyskrecjonalnych zmian niepieniężnych składników aktywów obrotowych netto}

Z analizy uzyskanych wyników badań empirycznych wynika, że model Dechow-Dicheva cechuje się słabszym stopniem dopasowania do danych doświadczalnych niż model Jones (zob. tabela 5). Przy ocenie zmienności 
bieżących różnic memoriałowych z wykorzystaniem przeszłych, obecnych oraz przyszłych operacyjnych przepływów pieniężnych jako predyktorów zmiennej zależnej odnotowano ok. 25\% spółek giełdowych charakteryzujących się zadowalającym zakresem dopasowania zmiennych objaśniających do zmiennej objaśnianej (wartość skorygowanego współczynnika determinacji $R^{2}>0,3$ ) oraz $13 \%$ przedsiębiorstw wykazujących dobry stopień dopasowania zmiennych egzogenicznych do zmiennej endogenicznej (wartość skorygowanego współczynnika determinacji $R^{2}>0,5$ ). Można jednocześnie odnotować, że jedynie dla $18 \%$ badanej populacji istnieją podstawy do odrzucenia hipotezy zerowej (przy poziomie istotności $\alpha=0,05$ ), mówiącej, że współczynnik $R^{2}$ jest nieistotny statystycznie. Przy przyjętym poziomie istotności $\alpha=0,01$ odsetek ten znacznie maleje i wynosi ok. $6 \%$.

Tabela 5. Stopień dopasowania modelu Dechow-Dicheva służącego do wyznaczania bieżących różnic memoriałowych $(C A C C)$ w spółkach przemysłowych

\begin{tabular}{|c|c|c|c|c|c|c|c|}
\hline \multicolumn{6}{|c|}{$\begin{array}{l}\text { Udział przedsiębiorstw, dla których współczynniki dopasowania } \\
\text { modelu osiągały wartości }\end{array}$} & \multicolumn{2}{|c|}{$\begin{array}{l}\text { Udział przedsię- } \\
\text { biorstw, dla których } \\
\text { obliczone współ- } \\
\text { czynniki dopasowania } \\
\text { modelu były istotne } \\
\text { statystycznie } \\
\text { dla danego poziomu } \\
\text { istotności }\end{array}$} \\
\hline$R^{2}>0,1$ & $R^{2}>0,3$ & $R^{2}>0,5$ & $\begin{array}{l}\text { skoryg. } \\
R^{2}>0,1\end{array}$ & $\begin{array}{l}\text { skoryg. } \\
R^{2}>0,3\end{array}$ & $\begin{array}{l}\text { skoryg. } \\
R^{2}>0,5\end{array}$ & $\begin{array}{c}p \text {-value }= \\
=0,05\end{array}$ & $\begin{array}{c}p \text {-value }= \\
=0,01\end{array}$ \\
\hline $97,18 \%$ & $77,46 \%$ & $40,85 \%$ & $56,34 \%$ & $25,35 \%$ & $12,68 \%$ & $18,31 \%$ & $5,63 \%$ \\
\hline
\end{tabular}

Źródło: opracowanie własne.

Rezultaty badań empirycznych wskazują (podobnie jak to miało miejsce w przypadku współczynników DACC szacowanych za pomocą modelu Jones), że dla ogółu giełdowych spółek przemysłowych charakterystyczne były ujemne średnie 12-letnie wartości bieżących dyskrecjonalnych różnic memoriałowych $D C A C C$ (zob. rys. 4). Choć wydawać by się mogło, że wartości współczynników $D C A C C$ w spółkach ukaranych przez KNF znacząco się różniły od wartości tychże miar w pozostałych jednostkach gospodarczych poddanych analizie, pogłębione badana empiryczne nie potwierdziły tego przypuszczenia. Na podstawie testu Manna-Whitneya-Wilcoxona nie uwidoczniono bowiem, by skala implementowanych praktyk rachunkowego zarządzania zyskiem w obszarze aktywów obrotowych netto w spółkach nieprzestrzegających wytycznych MSR/MSSF różniła się w sposób istotny statystycznie od skali i kierunków tego typu działań podejmowanych w innych przedsiębiorstwach wytwórczych (zob. tabela 6). 


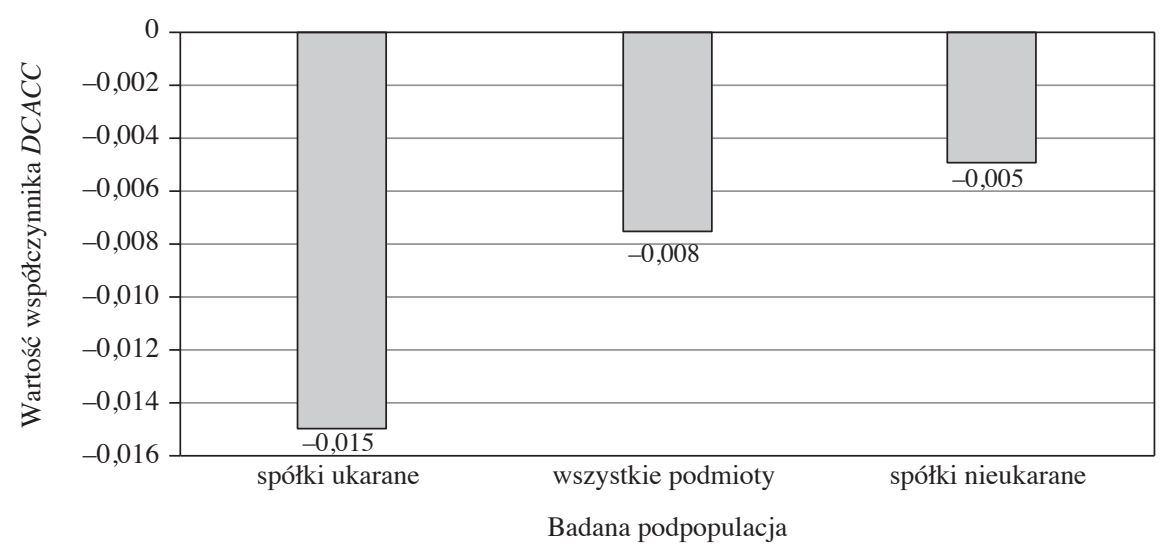

Rys. 4. Średnie 12-letnie wartości współczynnika dyskrecjonalnych bieżących różnic memoriałowych (szacowanych za pomocą modelu Dechow-Dicheva) w poszczególnych podpopulacjach

Źródło: opracowanie własne.

Tabela 6. Wyniki testu Manna-Whitneya-Wilcoxona dotyczącego statystycznego różnicowania zmiennej $D C A C C$ w obrębie spółek ukaranych i nieukaranych przez KNF

\begin{tabular}{|l|c|c|c|c|c|c|}
\hline \multicolumn{1}{|c|}{ Spółki } & $\begin{array}{c}\text { Średnia } \\
\text { ranga }\end{array}$ & Suma rang & $\begin{array}{c}U \text { Manna- } \\
\text {-Whitneya }\end{array}$ & $\begin{array}{c}W \\
\text { Wilcoxona }\end{array}$ & $Z$ & $\begin{array}{c}\text { Istotność } \\
\text { asymptotyczna }\end{array}$ \\
\hline $\begin{array}{l}\text { Niekarane } \\
(n=593)\end{array}$ & 402,41 & 238630,00 & 57277,00 & 77780,00 & $-0,928$ & 0,353 \\
\hline $\begin{array}{l}\text { Karane } \\
(n=202)\end{array}$ & 385,05 & 77780,00 & & & & \\
\hline
\end{tabular}

Źródło: opracowanie własne.

Analizując wyniki przeprowadzonych badań empirycznych nad kształtowaniem się średnich i środkowych wartości współczynnika intencjonalnych bieżących różnic memoriałowych $D C A C C$ w okresach, w odniesieniu do których KNF wykryła nieprawidłowości (okres $t$ ), jak również w latach poprzedzających $(t-2$, $t-1)$ lub bezpośrednio po nich następujących $(t+1, t+2)$, zauważyć można nieco inny trend niż ten, który towarzyszył rozkładowi współczynnika DACC (zob. rys. 5). Rezultaty analiz wskazują na to, że w okresach, za które KNF nakładała sankcje $(t)$, jak również bezpośrednio je poprzedzających $(t-1)$, notowano ujemne średnie wartości dyskrecjonalnych zmian niepieniężnych składników aktywów obrotowych netto. Natomiast w okresach pozostałych średnie wartości współczynnika $D C A C C$ były dodatnie. 


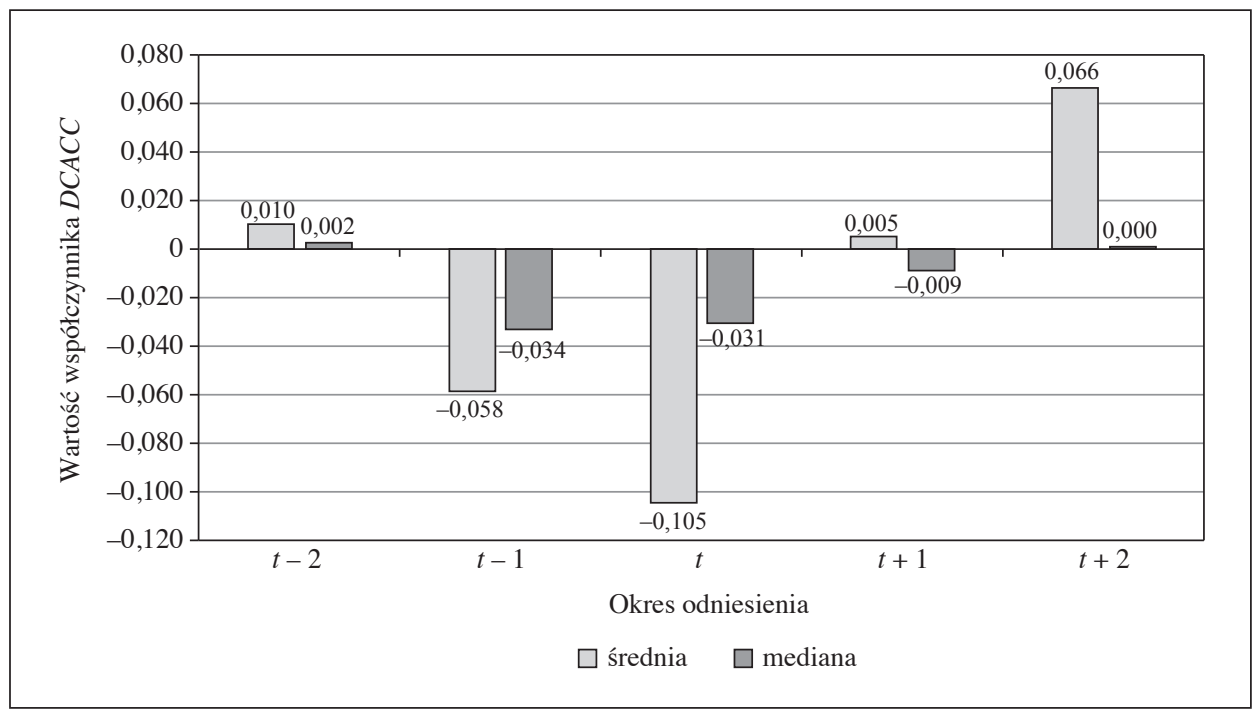

Rys. 5. Średnie i środkowe wartości współczynnika dyskrecjonalnych bieżących różnic memoriałowych $D C A C C$ obliczone dla spółek przemysłowych ukaranych przez KNF (według okresów)

Źródło: opracowanie własne.

Ponadto na podstawie testu znakowanych rang Wilcoxona stwierdzono występowanie istotnych statystycznie różnic między estymowanymi wartościami współczynników $D C A C C$ w stosunku do porównań dotyczących okresów $t$ i $t-2$ oraz $t$ i $t+2$ (zob. tabela 7). Przeprowadzone badania empiryczne wykazały bowiem, że statystycznie istotne różnice w zakresie kształtowania środkowych wartości współczynników $D C A C C$ zostały zaobserwowane w odniesieniu do okresów: $t$ i $t-2$ oraz $t \mathrm{i} t+2$.

Tabela 7. Analiza zmian wartości mediany współczynników dyskrecjonalnych bieżących różnic memoriałowych $D C A C C$ w spółkach przemysłowych ukaranych przez KNF za nieprzestrzeganie reguł MSR/MSSF

\begin{tabular}{|c|c|c|c|c|}
\hline $\begin{array}{c}\text { Porównywane } \\
\text { okresy }\end{array}$ & Wyszczególnienie & $N$ & Średnia ranga & Suma rang \\
\hline \multirow{4}{*}{$t / t-2$} & Ujemne rangi & 11 & 10,73 & 118,00 \\
\cline { 2 - 5 } & Dodatnie rangi & 6 & 5,83 & 35,00 \\
\cline { 2 - 5 } & Wiązania & 0 & - & - \\
\cline { 2 - 5 } & Ogółem & 17 & - & - \\
\cline { 2 - 5 } & $Z$ & $-1,965$ & - & - \\
\cline { 2 - 5 } & Istotność asymptotyczna & 0,049 & - & - \\
\hline
\end{tabular}


cd. tabeli 7

\begin{tabular}{|c|c|c|c|c|}
\hline $\begin{array}{c}\text { Porównywane } \\
\text { okresy }\end{array}$ & Wyszczególnienie & $N$ & Średnia ranga & Suma rang \\
\hline \multirow[t]{6}{*}{$t / t-1$} & Ujemne rangi & 11 & 8,64 & 95,00 \\
\hline & Dodatnie rangi & 6 & 9,67 & 58,00 \\
\hline & Wiązania & 0 & - & - \\
\hline & Ogółem & 17 & - & - \\
\hline & Z & $-0,876$ & - & - \\
\hline & Istotność asymptotyczna & 0,381 & - & - \\
\hline \multirow[t]{6}{*}{$t / t+1$} & Ujemne rangi & 11 & 7,00 & 42,00 \\
\hline & Dodatnie rangi & 6 & 10,09 & 111,00 \\
\hline & Wiązania & 0 & - & - \\
\hline & Ogółem & 17 & - & - \\
\hline & $Z$ & $-1,633$ & - & - \\
\hline & Istotność asymptotyczna & 0,102 & - & - \\
\hline \multirow[t]{6}{*}{$t / t+2$} & Ujemne rangi & 12 & 5,00 & 25,00 \\
\hline & Dodatnie rangi & 5 & 10,67 & 128,00 \\
\hline & Wiązania & 0 & - & - \\
\hline & Ogółem & 17 & - & - \\
\hline & $Z$ & $-2,438$ & - & - \\
\hline & Istotność asymptotyczna & 0,015 & - & - \\
\hline
\end{tabular}

Źródło: opracowanie własne.

\section{Podsumowanie}

Stopień, forma oraz czas ujmowania i prezentacji danych finansowych dla określonych adresatów determinowane są nie tylko prawnymi wymaganiami wynikającymi z istniejących uwarunkowań legislacyjnych, lecz także możliwościami kreatywnego kształtowania wyników finansowych dla osiągnięcia określonych celów. Implementacja tego typu praktyk niejednokrotnie wiąże się z nieprzestrzeganiem wytycznych zawartych w rozporządzaniach MSR/MSSF, brakiem ujawnień kluczowych informacji, opóźnianiem informacji poufnych itd.

Przeprowadzone badania empiryczne dotyczące kształtowania rachunkowego zarządzania zyskiem $\mathrm{w}$ przedsiębiorstwach przemysłowych ukaranych przez KNF w związku z niewypełnianiem lub nierzetelnym wypełnianiem obowiązku informacyjnego na podstawie przepisów prawa wykazały, że w podmiotach tych dominowały strategie intencjonalnego zmniejszania raportowanego wyniku finansowego netto. Jednocześnie obliczone średnie wartości współczynników dyskrecjonalnych 
całkowitych i bieżących różnic memoriałowych w podmiotach ukaranych nie różniły się w sposób istotny statystycznie od wartości tychże miar w pozostałych spółkach wytwórczych notowanych na GPW w Warszawie. Zrealizowane badania pokazały jednak, że wartości dyskrecjonalnych różnic memoriałowych wyznaczane dla okresów, w odniesieniu do których wykryto nieprawidłowości, ze statystycznego punktu widzenia różniły się od wartości intencjonalnych korekt zysku netto estymowanych dla okresów wcześniejszych i późniejszych. Może to sugerować, że znaczne odchylenia wartości dyskrecjonalnych różnic memoriałowych w obrębie danego przedsiębiorstwa obserwowane $\mathrm{z}$ roku na rok mogą być postrzegane jako sygnał świadczący o możliwości wystąpienia niedozwolonych praktyk księgowych.

Zrealizowane badania nie spełniają warunku generalizacji - nie mogą być uogólniane na wszystkie przedsiębiorstwa przemysłowe. Wskazują jednak na potrzebę kontynuacji badań naukowych nad zagadnieniami pomiaru jakości raportowanych danych rachunkowych oraz narzędzi predykcji zjawiska zarządzania zyskiem na polskim rynku kapitałowym.

\section{Literatura}

Albu N., Albu C.N., Vasile L.G., Mateescu R. (2014), Transparency and Quality of Financial Disclosures: The Case of Romanian Listed Companies, ,Zeszyty Teoretyczne Rachunkowości", nr 78(134), https://doi.org/10.5604/16414381.1122854.

Amara I. (2017), The Effect of Discretionary Accruals on Financial Statement Fraud: The Case of the French Companies, ,International Research Journal of Finance and Economics", nr 161, May.

Babalyan L. (2004), Earnings Management by Firms Applying International Financial Reporting Standards: Implications for Valuation, University of Fribourg, Switzerland.

Dechow P.M., Dichev I.D. (2002), The Quality of Accruals and Earnings: The Role of Accrual Estimation Errors, „The Accounting Review”, vol. 77, nr 1, https://doi. org/10.2308/accr.2002.77.s-1.35.

Fischer M., Rozenzweig K. (1995), Attitudes of Students and Accounting Practitioners Concerning the Ethical Acceptability of Earnings Management, „Journal of Business Ethics", vol. 14, nr 6, https://doi.org/10.1007/bf00872085.

Healy P.M., Wahlen J.M. (1999), A Review of the Earnings Management Literature and Its Implications for Standard Setting, ,Accounting Horizons”, vol. 13, $\mathrm{nr} 4$, https://doi. org/10.2308/acch.1999.13.4.365.

Hendryk M., Hońko S. (2017a), Analiza kar nałożonych przez KNF na spótki notowane na GPW za nieprawidłowości w zakresie pomiaru utraty wartości aktywów, „Finanse, Rynki Finansowe, Ubezpieczenia”, vol. 88, nr 4, https://doi.org/10.18276/ frfu.2017.88/1-05.

Hendryk M., Hońko S. (2017b), Przeglq̨ kar nałożonych przez Komisję Nadzoru Finansowego na spółki giełdowe za nieprzestrzeganie wytycznych MSR/MSSF, „Studia Ekonomiczne. Zeszyty Naukowe Uniwersytetu Ekonomicznego w Katowicach”, nr 333. 
Jensen M.C., Meckling W.H. (1976), Theory of the Firm: Managerial Behavior, Agency Costs and Ownership Structure, ,,Journal of Financial Economics”, vol. 3, nr 4, https:// doi.org/10.1016/0304-405x(76)90026-x.

Jones J. (1991), Earnings Management during Import Relief Investigations, ,Journal of Accounting Research", vol. 29, nr 2, https://doi.org/10.2307/2491047.

Kerstein J., Rai A. (2007), Working Capital Accruals and Earnings Management, ,Investment Management and Financial Innovations", vol. 4, nr 2.

Kształtowanie zysków podmiotów sprawozdawczych w Polsce. MSR/MSSF a ustawa o rachunkowości (2013), red. A. Piosik, Wydawnictwo C.H. Beck, Warszawa.

Mitchell R.K., Agle B.R., Wood D.J. (1997), Toward a Theory of Stakeholder Identification and Salience: Defining the Principle of Who and What Really Counts, ,The Academy of Management Review", vol. 22(4), https://doi.org/10.2307/259247.

Nita B. (2016), Teoria interesariuszy a informacja sprawozdawcza na przykładzie pryzmatu dokonań,,,Zeszyty Teoretyczne Rachunkowości”, vol. 87, nr 146.

Paiva I.S., Lourenço I.C., Branco M.C. (2016), Earnings Management in Family Firms: Current State of Knowledge and Opportunities for Future Research, ,Review of Accounting and Finance", vol. 15, nr 1, https://doi.org/10.1108/raf-06-2014-0065.

Rahman M.M., Moniruzzaman M., Sharif M.J. (2013), Techniques, Motives and Controls of Earnings Management, ,International Journal of Information Technology and Business Management", vol. 11, nr 1.

Schipper K. (1989), Commentary on Earnings Management, „Accounting Horizons”, vol. 3 , nr 4.

Smejda M. (2012), Determinanty zarzqdzania zyskami, „Studia Ekonomiczne”, nr 125.

Wójtowicz P. (2010), Wiarygodność sprawozdania finansowego wobec aktywnego kształtowania wyniku finansowego, Wydawnictwo Uniwersytetu Ekonomicznego w Krakowie, Kraków.

Wykaz kar nałożonych przez Komisję Nadzoru Finansowego za lata 2006-2018 (2019), https://bip.knf.gov.pl/pliki/kary_KNF_chronologicznie_tcm6-65884.pdf (data dostępu: 5.05.2019).

Yang S.S. (2005), Performance Measures, Discretionary Accruals and CEO Cash Compensation, Working Papers, https://pdfs.semanticscholar.org/f7f6/4467189055ab59e86b5838a55ae6e288644c.pdf (data dostępu: 20.03.2020).

\section{Earnings Management in Industrial Listed Companies Sanctioned by the Polish Financial Supervision Authority for Irregularities in Compliance with IAS/IFSR Guidance}

(Abstract)

Objective: The main aim of the paper is to analyse practices in the area of accrual-based earnings management in industrial joint-stock companies, among which the PFSA has detected irregularities in the failure to fulfill the obligation to provide information.

Research Design \& Methods: An analysis of total and current discretionary accrual, extracted using the Jones and Dechow-Dichev models, was used to determine the magnitude and directions of accrual-based earnings management. 
Findings: The empirical research shows that the companies studied predominantly use strategies to intentionally reduce the net financial results they report. It has been proved that the values of discretionary accruals determined for the periods for which irregularities were found clearly differed from the values of discretionary accruals estimated for earlier and later periods.

Implications / Recommendations: Significant deviations of the DACC and DCACC indicators observed from year to year can be seen as a warning signal indicating that fraudulent accounting practices may be occurring.

Contribution: The study contributes to the science by contributing to the search for increasingly precise tools to enable the assessment of qualitative features of financial statements of companies from the Polish capital market.

Keywords: accrual-based earnings management, the Polish Financial Supervision Authority, discretionary accruals, industrial enterprises. 